\title{
HIF-1 $\alpha$ and mTOR - Possible Novel Strategies of Targeted Therapies in p16-positive and -negative HNSCC
}

\author{
BENEDIKT KRAMER ${ }^{1}$, MAX POLIT ${ }^{1}$, RICHARD BIRK $^{2}$, NICOLE ROTTER $^{1}$ and CHRISTOPH ADERHOLD ${ }^{1}$ \\ ${ }^{1}$ Department of Otorhinolaryngology Head and Neck Surgery, \\ University Hospital Mannheim, Medical Faculty Mannheim, University Heidelberg, Mannheim, Germany; \\ ${ }^{2}$ Department of Otorhinolaryngology, Head and Neck Surgery, \\ University Hospital Marburg, Philips-Universität, Marburg, Germany
}

\begin{abstract}
Background/Aim: Targeted therapy in head and neck squamous cell carcinoma (HNSCC) is limited. HIF-1 $\alpha$ and MTOR are involved in the formation of local tumor progression and distant metastasis. The present study analyzed the influence of well-established tyrosine kinase inhibitors nilotinib, dasatinib, erlotinib and gefitinib on the expression of HIF-l $\alpha$ and mTOR in pl6-positive and -negative squamous cancer cells (SCC) in vitro in order to develop novel strategies in the treatment of HNSCC. Materials and Methods: Expression of HIF-1 $\alpha$ and mTOR was analyzed by using Sandwich-ELISA in p16-negative and p16-positive SCC after treatment with nilotinib, dasatinib, erlotinib and gefitinib (20 $\mu \mathrm{mol} / \mathrm{l}, 24-96 \mathrm{~h}$ of incubation). Results: All substances significantly reduced mTOR expression in both, p16-negative and p16-positive SCC $(p<0.05) . H I F-1 \alpha$ expression was significantly reduced by all tested substances in p16-negative SCC. However, a statistically significant increase of HIF-1 $\alpha$ was observed in p16-positive SCC. Conclusion: This is the first study to investigate the alteration of expression levels of HIF-1 $\alpha$ and mTOR under selective tyrosine kinase inhibition in both p16positive and -negative SCC. Our findings provide novel insights for a better understanding of HIF-1 $\alpha$ and $m$ TOR in the tumor biology of HNSCC and their interaction with selective small-molecule inhibitors.
\end{abstract}

This article is freely accessible online.

Correspondence to: Dr. med. Benedikt Kramer, Department of Otorhinolaryngology, Head and Neck Surgery, University Hospital Mannheim, Theodor-Kutzer-Ufer 1-3, 68167 Mannheim, Germany. Tel: +49 6213831600, Fax: +49 6213833827, e-mail: benedikt. kramer@umm.de

Key Words: mTOR, HIF- $1 \alpha$, head and neck squamous cell carcinoma, drug resistance, nilotinib, dasatinib, erlotinib, gefitinib.
Squamous cell carcinoma of the head and neck (HNSCC) is the sixth most common cancer with a global incidence of more than 680,000 cases (1). Environmental factors such as tobacco smoke and alcohol abuse are known to be the greatest risk factors for the development of $\operatorname{HNSCC}(2,3)$. The variety of therapeutic options includes surgery, radiation, platinum-based chemotherapy and immunotherapy. However, patients with advanced-stage or metastatic tumor disease still have limited therapeutic options and a poor prognosis (4-6).

Up to date, the status of human papillomavirus (HPV)association is mandatory and part of every pathological analysis of oropharyngeal tumor specimen as HPV-infection has be proven to be associated with oropharyngeal squamous cell carcinoma (7). Recently, HPV-status has been introduced in the staging criteria of oropharyngeal squamous cell carcinoma in the 8th Edition of the American Joint Committee on Cancer (AJCC) (8). Unlike a decrease of tobacco use in western countries, the incidence of oropharyngeal cancer has been rising $(9,10)$. More than 200 subtypes of HPV have been analysed but high-risk subtype 16 can be detected in approximately $90 \%$ of HPV-related oropharyngeal squamous cancer cells (11). The expression of two HPV-related oncogenic proteins, E6 and E7, is crucial for the carcinogenesis as p53 is degraded by E6 and an Retinoblastoma tumor suppressor protein is degraded by E7 $(12,13)$. HPV-positive squamous cell carcinoma of the oropharynx is associated with a favorable prognosis and a higher sensitivity to radiation $(14,15)$.

In the process of local tumor progression hypoxia triggers glycolysis as a response to a lack of oxygen which can lead to a formation of irregular tumor vascularization to enhance the nutritive support for the tumor microenvironment (16). Hypoxia-inducible factors (HIF) are up-regulated in the case of hypoxia and promote cell survival through the upregulation of glycolysis enzymes to enhance adenosine triphosphate (ATP) synthesis and vascular endothelial growth factor (VEGF) to promote neoangiogenesis $(17,18)$. Hypoxia also influences the sensitivity to local radiotherapy 
because free radical formation is dependent on oxygen to induce cell death by DNA strand breaks (19). Therefore, hypoxic tumor environment decreases the sensitivity to radiation $(20,21)$. Moreover, hypoxia is associated with an aggressive tumor phenotype and consequently leads to tumor progression (22). The ability of tumor cells to maintain nutrition during hypoxia is mediated by proteins like hypoxia-inducible factor 1 alpha (HIF-1 $\alpha$ ) (23). HIF- $1 \alpha$ is then stabilized and translocated into the nucleus and heterodimerizes with $\operatorname{HIF}-1 \beta(24,25)$. HIF-1 binds to hypoxia response elements (HRE) to promote the hypoxiainduced mechanisms. The acquirement of oxygenation by inhibitors of angiogenesis could therefore increase the sensitivity to radiation (26). The down-regulation of HIF-1 $\alpha$ could also be accomplished by suppression of the rat sarcoma (RAS)/rapidly accelerated fibrosarcoma (RAF) pathway (27). Targeting hypoxia could be a possible approach to sensitize tumor cells for radiation and consequently decrease the progression of local tumor growth.

The deregulation of key signaling pathways is crucial for the development of HNSCC. One of the most frequently modified pathways in cancerous disease is the phosphoinositide 3-kinase/protein kinase $\mathrm{B} /$ mammalian target of rapamycin (PI3K/AKT/mTOR) signaling pathway (28). mTOR is a downstream effector of AKT and activated mTOR promotes cell growth and proliferation, cell metabolism and T-cell activation (29). mTOR is part of two catalytic complexes, mTORC1 and mTORC2, which regulate protein translation through phosphorylation of key signaling proteins resulting in increased cell proliferation and angiogenesis (30). The activation of mTORC1 is mediated though AKT while mTORC2 activates AKT (31). The activation of PI3K is regulated by phosphatase and tensin homolog (PTEN). Loss-of-function mutation of PTEN is a main principle in cancer development which leads to an uncontrolled activation of PI3K/AKT/mTOR (32). The activation of mTOR can be induced by several regulators as increased expression of epidermal growth factor receptor (EGFR) or an inactivation of PTEN and has been detected in more than $80 \%$ in HNSCC, resulting in a poor prognosis $(33,34)$. Activated mTOR also increases the translation of HIF- $1 \alpha$ and therefore stimulates angiogenesis (35).

Targeted therapies have been introduced in the therapy of several cancers, including HNSCC. Nilotinib and dasatinib were at first designed for the treatment of chronic myeloid leukemia as alternative drugs for non-responders to first generation inhibitors of the breakpoint cluster region protein and Abelson murine leukemia viral oncogene (BCR-ABL) (36). Besides the effect on BCR-ABL, nilotinib and dasatinib use platelet derived growth factor receptor (PDGFR) and tyrosine-protein kinase KIT (cKIT) to mediate their antiproliferative effects whereas dasatinib additionally acts through the inhibition of Sarcoma tyrosine kinase (Src) (37).
Erlotinib and gefitinib are selective inhibitors of EGFR by a competitive inhibition of the ATP binding side to EGFR and subsequently reduce autophosphorylation (38). Gefitinib can be used in first-line therapy of non-small cell lung cancer (NSCLC) with a proven EGFR mutation whereas Erlotinib is currently in use applied for advanced or metastatic NSCLC and metastatic pancreatic cancer (39-41).

The effect of nilotinib, dasatinib, erlotinib and gefitinib on the expression of HIF-1 $\alpha$ and mTOR has not yet been demonstrated in HPV-related HNSCC. The aim of the current study was to evaluate the expression HIF-1 $\alpha$ and mTOR in p16-positive and -negative squamous cell carcinoma cells in vitro and gain novel insights in the tumor biology of HNSCC and propose additional information for possible new strategies for targeted therapies in HNSCC.

\section{Materials and Methods}

Cell lines. We used p16-negative cells originating from a primary SCC of human epiglottis (HNSCC 11A) and skin metastasis of a human floor of mouth SCC after surgery and radiation therapy (HNSCC 14C) (T.E. Carey, Ph.D., University of Michigang, Ann Arbor, USA). P16-positive cells were derived from human SCC of the uterine cervix (Cell Lines Service GmbH, Eppelheim, Germany). HNSCC 11A and HNSCC 14C were cultured with Eagle's minimum essential medium (Gibco, Life Technologies, Carlsbad, MA, USA) with a supplement of $2 \mathrm{mM}$ of L-glutamine and $10 \%$ fetal calf serum (Gibco, Life Technologies). Pen-Strep was added according to the manufacturer's instructions (Gibco, Life Technologies). Eagle's minimum essential medium was used for cell culture of CERV196 cells (Gibco, Life Technologies). The cell culture was supplemented with $2 \mathrm{mM}$ L-glutamine, $1 \mathrm{~g} / 1$ sodium bicarbonate, $1 \mathrm{~g} / 1$ sodium pyruvate, $0.1 \mathrm{mM}$ non-essential aminoacids and $10 \%$ of fetal bovine serum (Gibco, Life Technologies). Incubation was performed under standardized conditions at $37^{\circ} \mathrm{C}$, $5 \% \mathrm{CO}_{2}$ and $95 \%$ humidity. Subcultures were generated by using $0.05 \%$ trypsin $/ 0.02 \%$ EDTA EDTA solution for $5 \mathrm{~min}$ at $37^{\circ} \mathrm{C}$ (Sigma Aldrich, St. Louis, MO, USA). Incubation was performed for $24,48,72$ and $96 \mathrm{~h}$.

Selective tyrosine kinase inhibitors nilotinib, dasatinib, gefitinib and erlotinib were gratefully provided by Professor Hofheinz, Oncological Department, University Hospital Mannheim GmbH. The drugs were dissolved in dimethylsulfoxide at a concentration of $20 \mu \mathrm{mol} / 1$. 96-well microtiter plates were used for cell proliferation assay (alamarBlue ${ }^{\circledR}$, AbD Serotec, Oxford, UK). The experiments were independently repeated for three times $(n=3)$.

Enzyme-linked immunosorbent assay (ELISA) for total HIF-1 $\alpha$ and $m T O R$. ELISA technique was used for the determination of protein concentrations. Sandwich ELISA was performed for the quantitative measurement of HIF- $1 \alpha$ and mTOR. We used DuoSet ELISA development kits (R\&D Systems, Wiesbaden, Germany) for the two target proteins (DYC1665 and DYC1935, R\&D Systems, Wiesbaden, Germany) according to the manufacturers' instructions. The optical density was measured by MRX Microplate Reader (DYNEX Technologies, Chantilly, VA, USA) at a wavelength of $450 \mathrm{~nm}$ with a wavelength correction of $540 \mathrm{~nm}$. The calibrations on each microtiter plate included HIF- $1 \alpha$ and mTOR standards that 
were provided in the manufacturers' kits. Concentrations were recorded as $\mathrm{pg} / \mathrm{ml}$. The interassay coefficient of variation was below $10 \%$ according to the manufacturer.

Statistical analysis. Means of each experiment were generated and used for statistical analysis. Time of incubation, cell line and applied drug (including negative control) were used as determinants for multiplecoefficient variance test. Dunnett's test was performed to adjust $p$ values and analyse statistical significance (Version 9.3 SAS/STAT of SAS Institute Inc., Cary, NC, USA). For all analyses, $p \leq 0.05$ was considered to be statistically significant. Statistical analyses were performed in cooperation with Dr. Svetlana Hetjens, Institute of Biomathematics, University Hospital Mannheim GmbH, Germany.

\section{Results}

HIF-1 $\alpha$ expression levels in HNSCC 11A, 14C and CERV196. HIF-1 $\alpha$ expression was detected in every cell line tested. The levels of expression were constant in p16negative HNSCC 11A and HNSCC 14C. There was a marginally reduced expression in p16-positive CERV196 cells, however, without statistical significance. In HNSCC 11A expression of HIF- $1 \alpha$ was notably elevated after $48 \mathrm{~h}$ in the negative control and after treatment with dasatinib and gefitinib. Any of the tested substances decreased HIF-1 $\alpha$ expression statistically significant in any of the tested cell lines when compared to the negative control. In HNSCC 11A nilotinib reduced HIF-1 $\alpha$ expression statistically significant after $24(p=0.049), 48(p=0.003)$ and $72(p<0.001) h$ h. After $96 \mathrm{~h}$ of incubation the decreasing effect was without statistical significance. Dasatinib led to a statistically relevant increase of HIF- $1 \alpha$ in HNSCC $11 \mathrm{~A}$ only after $24 \mathrm{~h}$ $(p<0.001)$. After 48 and $72 \mathrm{~h}$, we observed an increase of expression, although not statistically significant. A decrease of HIF-1 $\alpha$ occurred after $96 \mathrm{~h}$ without statistical significance. Erlotinib reduced HIF-1 $\alpha$ expression in HNSCC $11 \mathrm{~A}$ after 24 to $96 \mathrm{~h}$, but with statistical significance only after 48,72 and $96 \mathrm{~h}(p \leq 0.002)$. A statistically significant decrease of HIF- $1 \alpha$ expression in HNSCC $11 \mathrm{~A}$ could be measured after incubation with gefitinib after 2496 h ( $p \leq 0.006$ ). For HNSCC 14C, HIF-1 $\alpha$ was significantly reduced after treatment with any of the tested drugs. HIF-1 $\alpha$ was significantly decreased after incubation with nilotinib after $24(p=0.005)$ and $48(p<0.001) \mathrm{h}$. A moderate increase of HIF- $1 \alpha$ in HNSCC $14 \mathrm{C}$ was seen after treatment with nilotinib after $72 \mathrm{~h}(p=0.567)$. Dasatinib decreased HIF-1 $\alpha$ expression levels in HNSCC 14C after 24 to $96 \mathrm{~h}$, although statistically significant only after 48 to $96 \mathrm{~h}(p \leq 0.002)$. Erlotinib and gefitnib decreased HIF-1 $\alpha$ expression in HNSCC $14 \mathrm{C}$ after 24 to $96 \mathrm{~h}$. A statistically significant reduction of HIF- $1 \alpha$ was observed after treatment with erlotinib after $48(p<0.001)$ and $96 \mathrm{~h}(p<0.001)$ and after treatment with gefitinib after $24(p=0.031), 48(p<0.001)$ and $96 \mathrm{~h}(p<0.001)$. In CERV196 HIF-1 $\alpha$ expression was not detected in the negative control after $24 \mathrm{~h}$, but after treatment with any of the tested substances. An expression of HIF- $1 \alpha$ was then detected after $48 \mathrm{~h}$ in the negative control. Surprisingly, the level of HIF-1 $\alpha$ expression was elevated after incubation with any of the tested drugs after $48 \mathrm{~h}$ with one exception for nilotinib. A statistically significant increase of HIF-1 $\alpha$ after $48 \mathrm{~h}$ in CERV196 was seen after treatment with erlotinib $(p=0.005)$ and gefitinib $(p=0.008)$. After 72 and $96 \mathrm{~h}$ of incubation the level of HIF$1 \alpha$ expression in CERV 196 was decreased after treatment with EGFR-inhibitors erlotinib and gefitinib, however, without statistical significance. On the contrary, the level of HIF- $1 \alpha$ in CERV196 was increased after treatment with nilotinib and dasatinib after $72 \mathrm{~h}$, but again, without statistical significance. After $96 \mathrm{~h}$, nilotinib led to a statistically significant increase of HIF- $1 \alpha$ expression in CERV196 $(p<0.001)$. Data are shown in Figure 1 and Table I (drug concentration of $20 \mu \mathrm{mol} / \mathrm{l}$ ). All statements related to statistically significant differences are comparisons referred to the negative control.

mTOR expression levels in HNSCC 11A, 14C and CERV196. mTOR expression was observed in every cell line tested. There was no significant difference in expression levels with respect to the p16 status. In HNSCC 11A, nilotinib led to a slight increase of mTOR expression after $24 \mathrm{~h}$ but afterwards the level of mTOR decreased after 48 to 96 hwith a statistically significant reduction after 72 and $96 \mathrm{~h}$ $(p<0.001)$. The exact same pattern was observed after incubation with erlotinib in HNSCC 11A. Dasatinib increased mTOR expression after 24 and $48 \mathrm{~h}$ however, without statistical significance. Then, after 72 and $96 \mathrm{~h}$, mTOR expression decreased statistically significant in HNSCC 11A $(p<0.001)$. A statistically significant decrease of mTOR expression in HNSCC 11A was also detected after treatment with gefitinib after 72 and $96 \mathrm{~h}(p<0.001)$ whereas mTOR expression was initially increased after $48 \mathrm{~h}$. In HNSCC 14C, mTOR expression was significantly decreased by dasatinib, erlotinib and gefitinib after $96 \mathrm{~h}$ of incubation $(p<0.001)$. For nilotinib, a statistically significant reduction was only observed after $72 \mathrm{~h}$ of incubation $(p=0.034)$ but a decrease of mTOR expression after treatment with nilotinib was notable for any point of time in HNSCC 14C. The expression levels of mTOR after treatment with dasatinib in HNSCC $14 \mathrm{C}$ decreased after 24 to $96 \mathrm{~h}$ with a statistically significant decrease after 72 and $96 \mathrm{~h}(p<0.001)$. Erlotinib initially increased mTOR expression after $24 \mathrm{~h}$ in HNSCC $14 \mathrm{C}$, but without statistical significance. Then, mTOR expression levels decreased again after 48 to $96 \mathrm{~h}$ with a statistically relevant reduction after $48(p=0.014)$ and $96 \mathrm{~h}$ $(p<0.001)$. In p16-negative HNSCC $14 \mathrm{C}$, mTOR expression was decreased after treatment with gefitinib with an exception after $72 \mathrm{~h}$, but without statistical significance. In p16-positive CERV196 we observed a reduction of mTOR 
HNSCC $11 \mathrm{~A}$

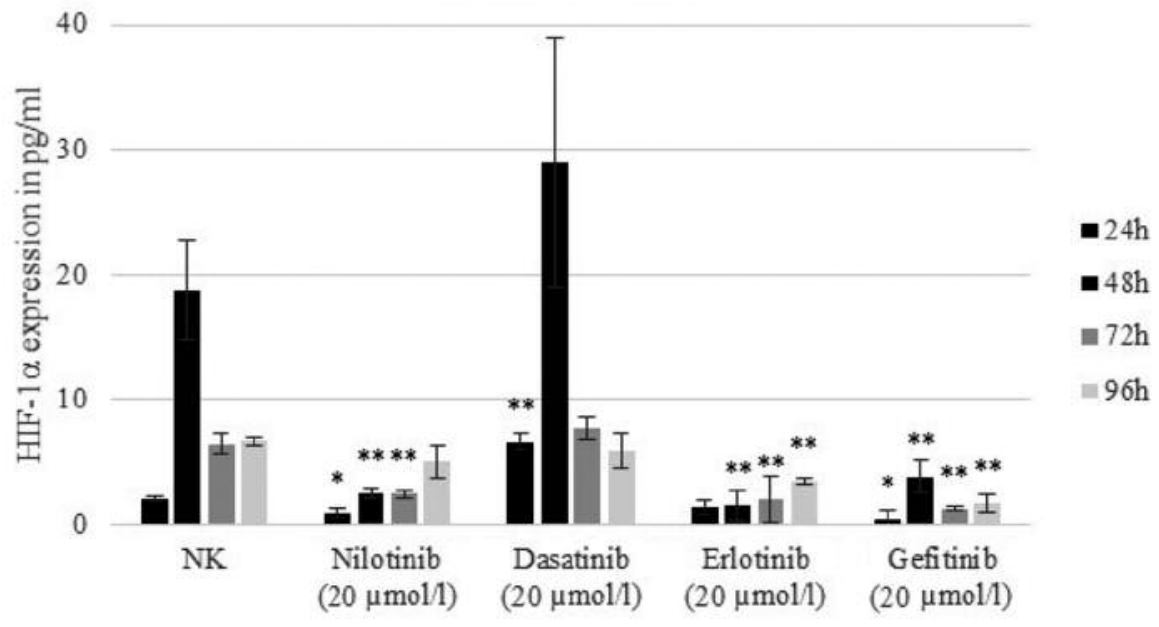

HNSCC $14 \mathrm{C}$

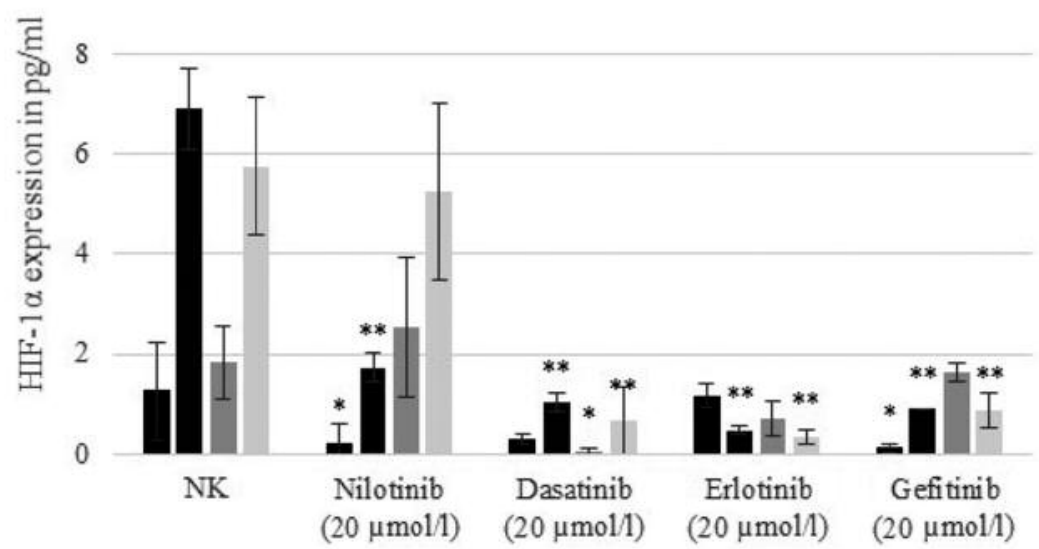

- $24 \mathrm{~h}$

- $48 \mathrm{~h}$

- $72 \mathrm{~h}$

$=96 \mathrm{~h}$

\section{CERV196}

10

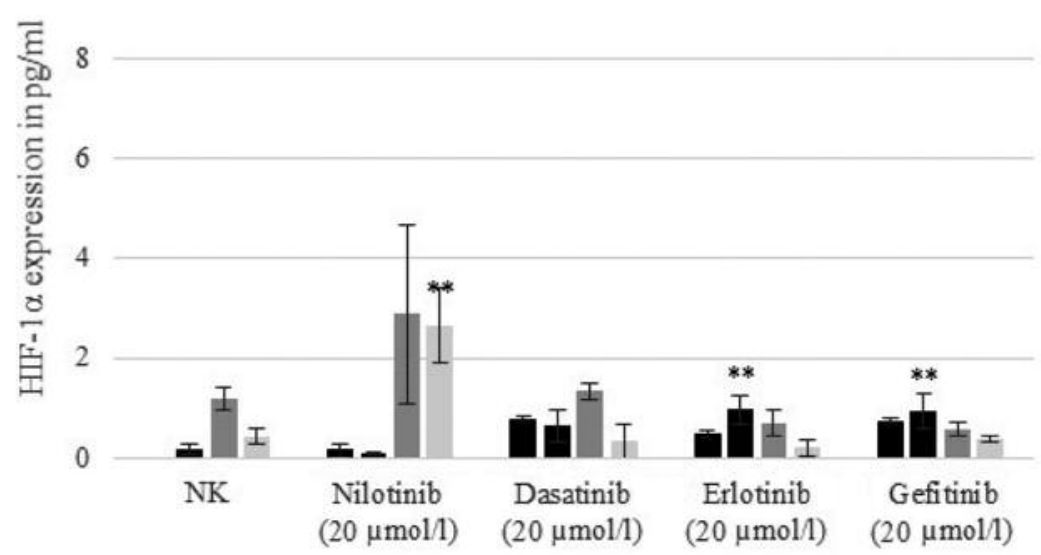

- $48 \mathrm{~h}$

프 $72 \mathrm{~h}$

$=96 \mathrm{~h}$

Figure 1. HIF-1 $\alpha$ expression in HNSCC 11A, 14C and CERV196 after incubation with nilotinib, dasatinib, erlotinib or gefitinib compared to the negative control. Data are mean values. Standard deviation is indicated. 
Table I. HIF-1 $\alpha$ expression in HNSCC 11A, 14C and CERV196 after incubation with nilotinib, dasatinib, erlotinib or gefitinib compared to the negative control. Statistically significant differences $(p<0.05)$ are shown in bold.

\begin{tabular}{|c|c|c|c|c|c|c|c|c|c|}
\hline \multirow[t]{2}{*}{$\begin{array}{l}\text { Incubation time } \\
\text { (h) }\end{array}$} & \multirow{2}{*}{$\begin{array}{c}\begin{array}{c}\text { Negative } \\
\text { control }\end{array} \\
\text { Mean }\end{array}$} & \multirow{2}{*}{$\begin{array}{c}\begin{array}{c}\text { Nilotinib } \\
(20 \mu \mathrm{mol} / \mathrm{l})\end{array} \\
\text { Mean }\end{array}$} & \multicolumn{3}{|c|}{$\begin{array}{l}\text { Dasatinib } \\
(20 \mu \mathrm{mol} / \mathrm{l})\end{array}$} & \multirow{2}{*}{$\begin{array}{c}\begin{array}{c}\text { Erlotinib } \\
(20 \mu \mathrm{mol} / \mathrm{l})\end{array} \\
\text { Mean }\end{array}$} & \multicolumn{3}{|c|}{$\begin{array}{l}\text { Gefitinib } \\
(20 \mu \mathrm{mol} / \mathrm{l})\end{array}$} \\
\hline & & & $p$-Value & Mean & $p$-Value & & $p$-Value & Mean & $p$-Value \\
\hline \multicolumn{10}{|l|}{ HNSCC 11A } \\
\hline 24 & 2.02 & 0.83 & 0.049 & 6.64 & $<0.001$ & 1.33 & 0.357 & 0.45 & 0.010 \\
\hline 48 & 18.74 & 2.50 & 0.003 & 28.96 & 0.059 & 1.53 & 0.002 & 3.88 & 0.006 \\
\hline 72 & 6.46 & 2.49 & $<0.001$ & 7.69 & 0.340 & 2.01 & $<0.001$ & 1.28 & $<0.001$ \\
\hline 96 & 6.67 & 5.07 & 0.136 & 5.89 & 0.679 & 3.46 & 0.002 & 1.67 & $<0.001$ \\
\hline \multicolumn{10}{|l|}{ HNSCC $14 \mathrm{C}$} \\
\hline 24 & 1.26 & 0.22 & 0.005 & 0.30 & 0.075 & 1.16 & 0.999 & 0.12 & 0.031 \\
\hline 48 & 6.91 & 1.73 & $<0.001$ & 1.02 & $<0.001$ & 0.47 & $<0.001$ & 0.89 & $<0.001$ \\
\hline 72 & 1.83 & 2.55 & 0.567 & 0.07 & 0.020 & 0.71 & 0.212 & 1.63 & 0.995 \\
\hline 96 & 5.75 & 5.26 & 0.951 & 0.65 & $<0.001$ & 0.35 & $<0.001$ & 0.86 & $<0.001$ \\
\hline \multicolumn{10}{|l|}{ CERV196 } \\
\hline 24 & 0.00 & 0.17 & 0.184 & 0.79 & $<0.001$ & 0.49 & $<0.001$ & 0.74 & $<0.001$ \\
\hline 48 & 0.19 & 0.10 & 0.983 & 0.65 & 0.110 & 0.98 & 0.005 & 0.94 & 0.008 \\
\hline 72 & 1.21 & 2.88 & 0.064 & 1.34 & 0.999 & 0.70 & 0.868 & 0.59 & 0.765 \\
\hline 96 & 0.44 & 2.66 & $<0.001$ & 0.34 & 0.996 & 0.21 & 0.897 & 0.38 & 0.999 \\
\hline
\end{tabular}

expression by nilotinib after any point of time. A statistically significant reduction was only observed after $72 \mathrm{~h}$ $(p=0.024)$. The expression of mTOR in CERV196 was initially elevated after treatment with dasatinib after $24 \mathrm{~h}$ but then decreased after 48 to $96 \mathrm{~h}$ with a statistically significant decrease after 72 and $96 \mathrm{~h}(p<0.001)$. The same pattern was observed after treatment with erlotinib in CERV196 with a statistically significant decrease of mTOR expression levels after $72(p<0.001)$ and $96 \mathrm{~h}(p=0.003)$. Surprisingly, mTOR expression in CERV196 was initially elevated by gefitinib after $24 \mathrm{~h}(p=0.05)$ and then decreased after 48, 72 and 96 $\mathrm{h}$ of incubation. A statistically significant decrease was only observed after $72 \mathrm{~h}(p<0.001)$. Data are shown in Figure 2 and Table II (drug concentration of $20 \mu \mathrm{mol} / \mathrm{l}$ ). All statements related to statistically significant differences are comparisons referred to the negative control.

\section{Discussion}

In this study we analyzed the alteration of the expression of HIF- $1 \alpha$ and mTOR in the presence of selective tyrosine kinase inhibitors nilotinib, dasatinib, gefitinib and erlotinib in p16-positive and -negative squamous tumor cells in vitro.

The investigation of selective tyrosine kinase inhibitors in HPV-associated squamous cell carcinoma has already been introduced regarding key signalling proteins that are associated with the tumor growth $(42,43)$. The activation of $\mathrm{PI} 3 \mathrm{~K} / \mathrm{AKT} / \mathrm{mTOR}$ has been detected in many types of cancers and is associated with local tumor progression and the formation of a favourable tumor microenvironment (44).
It has been reported that genomic mutations in the HNSCC genome affect the PI3K-mTOR pathway in over 30\% (28). The function of mTOR is essential as it is an important regulatory kinase which is involved in the stimulation of several key signalling processes as proliferation, survival and angiogenesis (45). We observed that all tested substances significantly decreased the expression of mTOR in every cell line tested. Furthermore, the effects were independent of the p16-status. None of the tested drugs acts as direct inhibitor of mTOR. However, several studies have been performed to investigate the effect of combined BCR-ABL and mTOR inhibition (46-48). In these studies, the promising results of a combined targeted therapy by using nilotinib and everolismus indicate synergistic effects of both substances by modifying the tumor stromal reduction to provide optimal conditions for the response to the target inhibition (49). Our findings help give rise to the question how the tyrosine kinase inhibitors influence mTOR expression in squamous cell carcinoma cells. One possible explanation could be that nilotinib and dasatinib, not only affect BCR-ABL, but also PDGFRs that act as downstream mediators of AKT and mTOR. Sabha and colleagues showed that nilotinib inhibited PDGFR- $\alpha$ and PDGFR- $\beta$ and consequently decreased mTOR expression in vestibular schwannoma cells (50). Our findings are also consistent with the findings of Boehrer et al. who demonstrated a decrease of mTOR activation by erlotinib in acute myeloid leukemia cells (51). The results, therefore, suggest indirect inhibiting mechanisms of mTOR by the inhibition of upstream regulators as PI3K which are affected by activated extracellular protein ligands like EGFR. The 


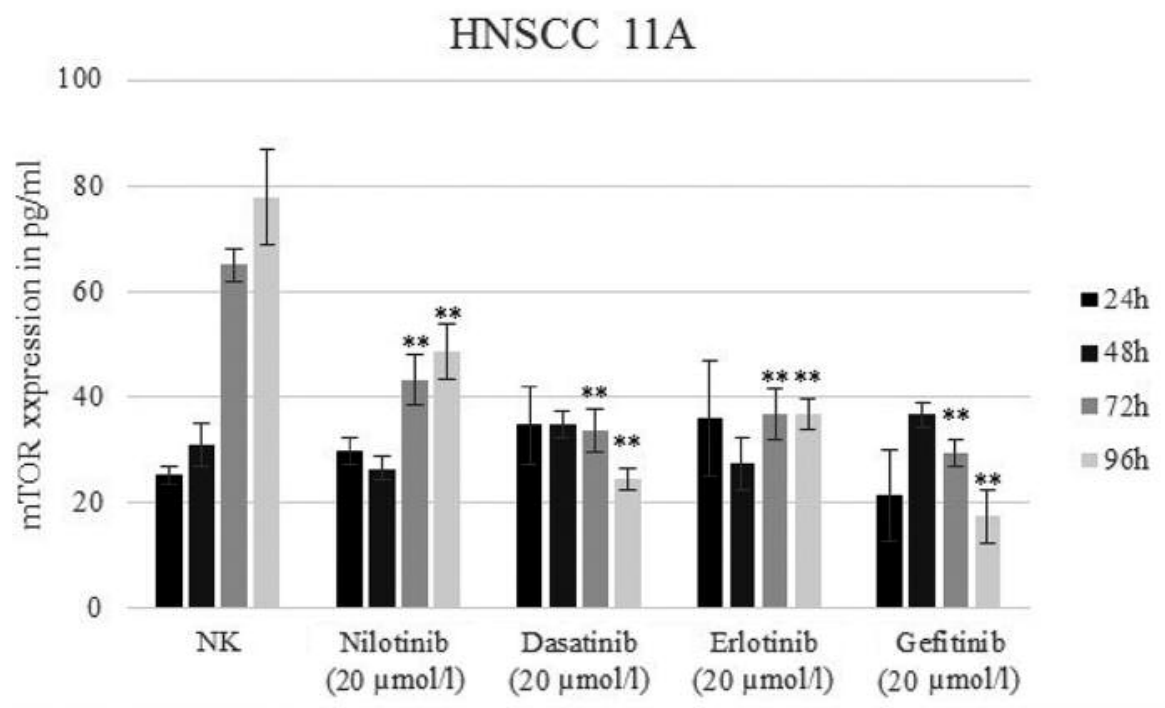

HNSCC $14 \mathrm{C}$
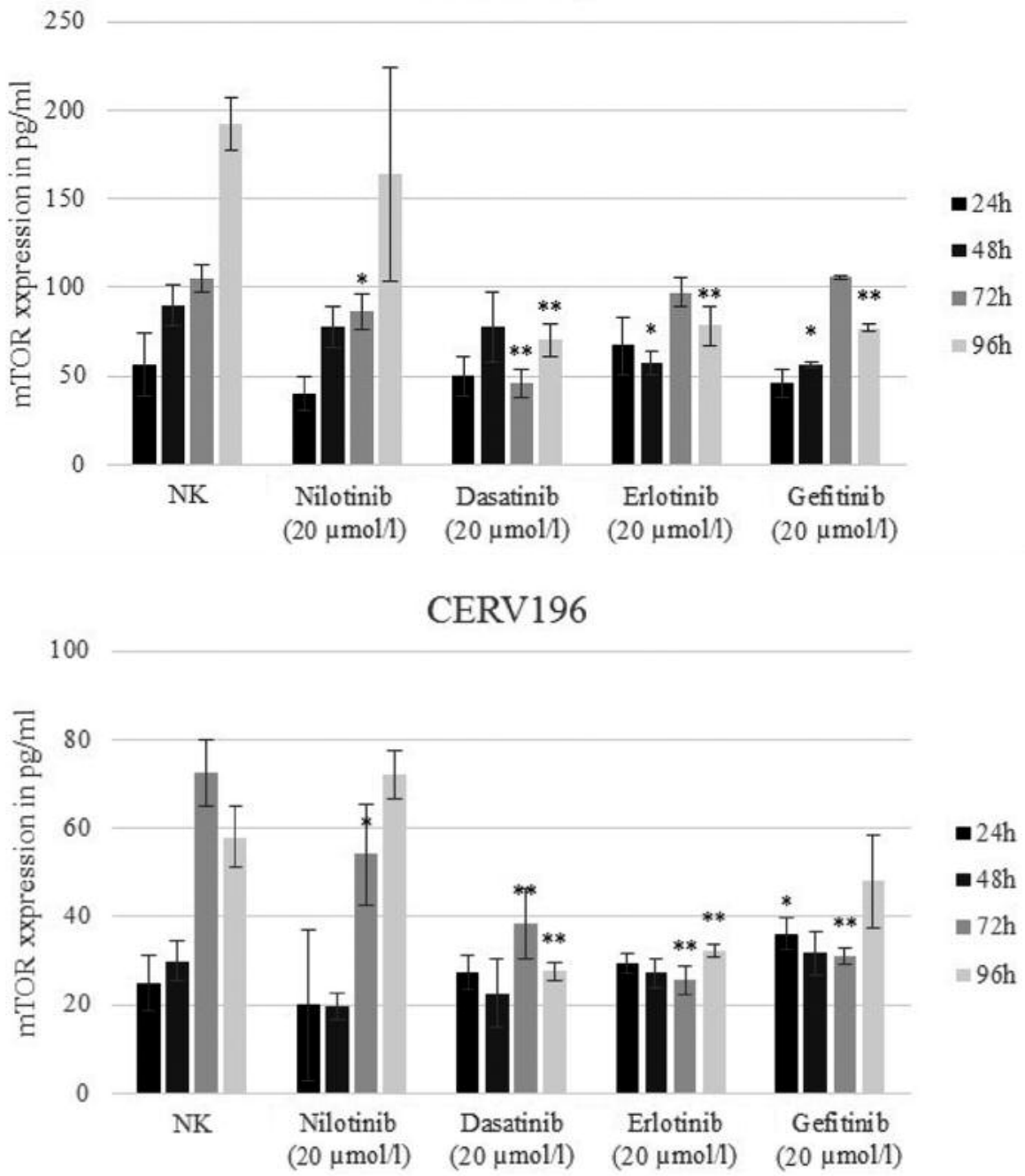

Figure 2. MTOR expression in HNSCC 11A, 14C and CERV196 after incubation with nilotinib, dasatinib, erlotinib or gefitinib compared to the negative control. Data are mean values. Standard deviation is indicated. 
Table II. mTOR expression in HNSCC 11A, 14C and CERV196 after incubation with nilotinib, dasatinib, erlotinib or gefitinib compared to the negative control. Statistically significant differences $(p<0.05)$ are shown in bold.

\begin{tabular}{|c|c|c|c|c|c|c|c|c|c|}
\hline \multirow[t]{2}{*}{$\begin{array}{l}\text { Incubation time } \\
\text { (h) }\end{array}$} & \multirow{2}{*}{$\begin{array}{c}\begin{array}{c}\text { Negative } \\
\text { control }\end{array} \\
\text { Mean }\end{array}$} & \multirow{2}{*}{$\begin{array}{c}\begin{array}{c}\text { Nilotinib } \\
(20 \mu \mathrm{mol} / \mathrm{l})\end{array} \\
\text { Mean }\end{array}$} & \multicolumn{3}{|c|}{$\begin{array}{l}\text { Dasatinib } \\
(20 \mu \mathrm{mol} / \mathrm{l})\end{array}$} & \multirow{2}{*}{$\begin{array}{c}\begin{array}{c}\text { Erlotinib } \\
(20 \mu \mathrm{mol} / \mathrm{l})\end{array} \\
\text { Mean }\end{array}$} & \multicolumn{3}{|c|}{$\begin{array}{l}\text { Gefitinib } \\
(20 \mu \mathrm{mol} / \mathrm{l})\end{array}$} \\
\hline & & & $p$-Value & Mean & $p$-Value & & $p$-Value & Mean & $p$-Value \\
\hline \multicolumn{10}{|l|}{ HNSCC 11A } \\
\hline 24 & 25.00 & 29.67 & 0.850 & 34.67 & 0.304 & 36.00 & 0.209 & 21.33 & 0.933 \\
\hline 48 & 31.00 & 26.33 & 0.481 & 34.67 & 0.680 & 27.33 & $0, .680$ & 36.67 & 0.316 \\
\hline 72 & 65.00 & 43.33 & $<0.001$ & 33.67 & $<0.001$ & 36.67 & $<0.001$ & 29.33 & $<0.001$ \\
\hline 96 & 77.67 & 48.67 & $<0.001$ & 24.33 & $<0.001$ & 36.67 & $<0.001$ & 17.33 & $<0.001$ \\
\hline \multicolumn{10}{|l|}{ HNSCC 14C } \\
\hline 24 & 56.33 & 39.67 & 0.362 & 50.00 & 0.948 & 67.00 & 0.729 & 45.67 & 0.727 \\
\hline 48 & 89.67 & 77.67 & 0.558 & 77.33 & 0.534 & 57.33 & 0.014 & 56.67 & 0.013 \\
\hline 72 & 10.00 & 86.33 & 0.034 & 45.67 & $<0.001$ & 97.00 & 0.558 & 105.67 & 1.0000 \\
\hline 96 & 192.33 & 164.00 & 0.565 & 70.33 & $<0.001$ & 78.33 & $<0.001$ & 77.00 & $<0.001$ \\
\hline \multicolumn{10}{|l|}{ CERV196 } \\
\hline 24 & 25.00 & 20.00 & 0.568 & 27.33 & 0.955 & 29.33 & 0.683 & 36.00 & 0.050 \\
\hline 48 & 30.00 & 19.67 & 0.093 & 22.67 & 0.302 & 27.33 & 0.942 & 31.67 & 0.992 \\
\hline 72 & 72.33 & 54.00 & 0.024 & 38.33 & $<0.001$ & 25.77 & $<0.001$ & 31.00 & $<0.001$ \\
\hline 96 & 58.00 & 72.00 & 0.105 & 27.67 & $<0.001$ & 32.33 & 0.003 & 48.00 & 0.321 \\
\hline
\end{tabular}

activation of mTOR in HPV-related tumors occurs in more than $60 \%$, outlining the significant role of mTOR in the appearance of p16-associated tumors (52). In our previous work we already showed a distinct decrease of mTOR expression in both p16-negative and p16-positive squamous cancer cells by direct mTOR inhibition (53). The activity of mTOR can be regulated through AKT signalling and through direct enhanced phosphorylation of mTOR through p16associated oncoprotein E6 (52). Indirect inhibition of mTOR through PDGFR inhibition or EGFR inhibition significantly reduced mTOR expression in p16-associated tumor cells. This indicates that the additional support to sustain mTOR activity through E6 might be compromised by indirect inhibitors of mTOR. Therefore, these tyrosine kinase inhibitor proteins might be suitable to destabilise the continuous support in p16related squamous tumor cells that are needed to maintain antiapoptotic and proliferative supply for continuous tumor progression. Further studies to investigate the role of mTOR in the tumor microenvironment of HNSCC are mandatory to understand the influence of selective tyrosine kinase inhibitors. Our findings could be useful to detect possible vulnerable targets for a better understanding and a more selective use of targeted therapy in HNSCC.

Tumor vascularization is dependent on many variables and is necessary for the progression of the tumor as well as the formation of lymphonodal and distant metastasis. Hypoxiamediated effects lead to an overexpression of proangiogenic factors and are linked by HIF-1 and HIF-2 (54). It is, therefore, reasonable to observe the reaction of HIF- $1 \alpha$ on potent selective tyrosine kinase inhibitors. The suppression of HIF-1 $\alpha$ could prevent neovascularization and hinder tumor progression. Moreover, it has been reported that a lack of oxygen would indeed lead to a repression of abnormal tumor vasculature and could paradoxically improve oxygenation with a better sensitivity to radiation (26). In HNSCC, EGFR mediated signalling is important for angiogenesis through HIF- $1 \alpha$ and translocation-associated Notch homolog 1 (Notch1) (55). We found that the expression of HIF- $1 \alpha$ was decreased by all tested substances in p16-negative HNSCC with one exception for dasatinib after $24 \mathrm{~h}$. Wang and colleagues demonstrated that EGFR expression is correlated with a higher HIF-1 $\alpha$ expression in adenoid cystic carcinoma cells of the salivary gland in head and neck (56). Our findings are consistent with this observation as EGFR inhibitors erlotinib and gefitinib significantly reduced HIF-1 $\alpha$ levels in p16-negative cancer cells. In another study of Pore et al., VEGF expression was decreased by gefitinib and erlotinib via two possible mechanisms, a down-regulation of HIF-1 $\alpha$ and a decrease of the specificity protein 1 (Sp1) binding to the proximal core VEGF promoter (57). This could be another possible mechanism to explain the down-regulation of HIF- $1 \alpha$ by erlotinib and gefitinib in p16-negative HNSCC. Nilotinib and dasatinib inhibit not only BCR-ABL, but also PDGFR and cKIT and dasatinib also inhibitis Src expression. As previously described, the expression of EGFR positively correlates with HIF- $1 \alpha$ expression. The degradation of EGFR is a possible mechanism discussed for dasatinib-induced apoptosis (58). Therefore, this degradation could affect HIF-1 $\alpha$ expression in HNSCC. In a previous study we could also observe decreasing EGFR levels in p16-negative and p16positive HNSCC in vitro (59). Another possible mechanism 
for the EGFR reduction could be that dasatinib decreases cell proliferation by effective Src inhibition which has been shown in NSCLC EGFR-expressing cells (60). Surprisingly, we observed an increase of HIF- $1 \alpha$ in p16-positive CERV196 cells under the influence of all tested drugs, especially after treatment with erlotinib and gefitinib. In a study of Kim et al. HPV-associated tumor cells of tonsillar cancer showed an inverse correlation association with EGFR amplification compared to p16-negative cancer cells (61). This could be a possible explanation why EGFR inhibitors such as erlotinib and gefitinib could not decrease HIF- $1 \alpha$ expression because the target protein was not amplified. HPV-related oncogene E6 could therefore lead to an up-regulation of HIF-1 $\alpha$ (62). Moreover, there could be unknown HPV-related mechanisms of drug resistance that would affect the impact of selective EGFR tyrosine kinase inhibitors. In response to tyrosine kinase-inhibiting proteins HPV-related cells could also provide proangiogenic factors like VEGF or HIF-1 $\alpha$ as compensatory up-regulation mechanisms to keep up support for tumor vascularization $(63,64)$.

In conclusion, this is the first study that analyses the effect of nilotinib, dasatinib, erlotinib and gefitinib on the expression of mTOR and HIF-1 $\alpha$ in p16-negative and -positive SCC cells in vitro. Our findings provide novel insights in the response of the tumor biology of squamous cell carcinomas with respect to HPV status to selective tyrosine kinase inhibitors. Our data provide novel information for a better understanding of selective tyrosine kinase inhibition and could be useful to improve targeted therapies in the treatment of HNSCC.

\section{Acknowledgements}

The Authors thank Petra Prohaska, Mannheim, Germany, for technical support and Dr S. Hetjens, Institute of Biomathematics, Faculty of Medicine, Mannheim, Germany, for advice in statistical analysis.

\section{References}

1 Ferlay J, Soerjomataram I, Dikshit R, Eser S, Mathers C, Rebelo M, Parkin DM, Forman D and Bray F: Cancer incidence and mortality worldwide: Sources, methods and major patterns in globocan 2012. Int J Cancer 136(5): E359-386, 2015.

2 Hashibe M, Brennan P, Benhamou S, Castellsague X, Chen C, Curado MP, Dal Maso L, Daudt AW, Fabianova E, Fernandez L, Wunsch-Filho V, Franceschi S, Hayes RB, Herrero R, Koifman S, La Vecchia C, Lazarus P, Levi F, Mates D, Matos E, Menezes A, Muscat J, Eluf-Neto J, Olshan AF, Rudnai P, Schwartz SM, Smith E, Sturgis EM, Szeszenia-Dabrowska N, Talamini R, Wei Q, Winn DM, Zaridze D, Zatonski W, Zhang ZF, Berthiller J and Boffetta P: Alcohol drinking in never users of tobacco, cigarette smoking in never drinkers, and the risk of head and neck cancer: Pooled analysis in the international head and neck cancer epidemiology consortium. J Natl Cancer Inst 99(10): 777-789, 2007.
3 Hashibe M, Brennan P, Chuang SC, Boccia S, Castellsague X, Chen C, Curado MP, Dal Maso L, Daudt AW, Fabianova E, Fernandez L, Wunsch-Filho V, Franceschi S, Hayes RB, Herrero R, Kelsey K, Koifman S, La Vecchia C, Lazarus P, Levi F, Lence JJ, Mates D, Matos E, Menezes A, McClean MD, Muscat J, ElufNeto J, Olshan AF, Purdue M, Rudnai P, Schwartz SM, Smith E, Sturgis EM, Szeszenia-Dabrowska N, Talamini R, Wei Q, Winn DM, Shangina O, Pilarska A, Zhang ZF, Ferro G, Berthiller J and Boffetta P: Interaction between tobacco and alcohol use and the risk of head and neck cancer: Pooled analysis in the international head and neck cancer epidemiology consortium. Cancer Epidemiol Biomarkers Prev 18(2): 541-550, 2009.

4 Siegel RL, Miller KD and Jemal A: Cancer statistics, 2015. CA Cancer J Clin 65(1): 5-29, 2015.

5 Sepiashvili L, Hui A, Ignatchenko V, Shi W, Su S, Xu W, Huang SH, O'Sullivan B, Waldron J, Irish JC, Perez-Ordonez B, Liu FF and Kislinger T: Potentially novel candidate biomarkers for head and neck squamous cell carcinoma identified using an integrated cell line-based discovery strategy. Mol Cell Proteomics 11(11): 1404-1415, 2012.

6 Kanazawa T, Misawa K, Misawa Y, Uehara T, Fukushima H, Kusaka G, Maruta M and Carey TE: G-protein-coupled receptors: Next generation therapeutic targets in head and neck cancer? Toxins (Basel) 7(8): 2959-2984, 2015.

7 D'Souza G, Kreimer AR, Viscidi R, Pawlita M, Fakhry C, Koch WM, Westra WH and Gillison ML: Case-control study of human papillomavirus and oropharyngeal cancer. $\mathrm{N}$ Engl J Med 356(19): 1944-1956, 2007.

8 Lydiatt WM, Patel SG, O'Sullivan B, Brandwein MS, Ridge JA, Migliacci JC, Loomis AM and Shah JP: Head and neck cancersmajor changes in the american joint committee on cancer eighth edition cancer staging manual. CA Cancer J Clin 67(2): 122-137, 2017.

9 Mehanna H, Beech T, Nicholson T, El-Hariry I, McConkey C, Paleri V and Roberts S: Prevalence of human papillomavirus in oropharyngeal and nonoropharyngeal head and neck cancer systematic review and meta-analysis of trends by time and region. Head Neck 35(5): 747-755, 2013.

10 Chaturvedi AK, Anderson WF, Lortet-Tieulent J, Curado MP, Ferlay J, Franceschi S, Rosenberg PS, Bray F and Gillison ML: Worldwide trends in incidence rates for oral cavity and oropharyngeal cancers. J Clin Oncol 31(36): 4550-4559, 2013.

11 Ndiaye C, Mena M, Alemany L, Arbyn M, Castellsague X, Laporte L, Bosch FX, de Sanjose S and Trottier H: Hpv DNA, e6/e7 mrna, and p16ink4a detection in head and neck cancers: A systematic review and meta-analysis. Lancet Oncol 15(12): 1319-1331, 2014.

12 Lopez-Ocejo O, Viloria-Petit A, Bequet-Romero M, Mukhopadhyay D, Rak J and Kerbel RS: Oncogenes and tumor angiogenesis: The hpv-16 e6 oncoprotein activates the vascular endothelial growth factor (vegf) gene promoter in a p53 independent manner. Oncogene 19(40): 4611-4620, 2000.

13 Boyer SN, Wazer DE and Band V: E7 protein of human papilloma virus-16 induces degradation of retinoblastoma protein through the ubiquitin-proteasome pathway. Cancer Res 56(20): 4620-4624, 1996.

14 Ang KK, Harris J, Wheeler R, Weber R, Rosenthal DI, NguyenTan PF, Westra WH, Chung CH, Jordan RC, Lu C, Kim H, Axelrod R, Silverman CC, Redmond KP and Gillison ML: Human papillomavirus and survival of patients with oropharyngeal cancer. N Engl J Med 363(1): 24-35, 2010. 
15 Nasman A, Bersani C, Lindquist D, Du J, Ramqvist T and Dalianis T: Human papillomavirus and potentially relevant biomarkers in tonsillar and base of tongue squamous cell carcinoma. Anticancer Res 37(10): 5319-5328, 2017.

16 Gammon L and Mackenzie IC: Roles of hypoxia, stem cells and epithelial-mesenchymal transition in the spread and treatment resistance of head and neck cancer. J Oral Pathol Med 45(2): 7782, 2016.

17 Hao LS, Wang G, Qian K, Luo T, Li XJ and Wu XT: hif-1alpha expression and relationship involving tumor cell proliferation and angiogenesis in human breast carcinoma. Sichuan Da Xue Xue Bao Yi Xue Ban 38(1): 60-63, 2007.

18 Chiavarina B, Martinez-Outschoorn UE, Whitaker-Menezes D, Howell A, Tanowitz HB, Pestell RG, Sotgia F and Lisanti MP: Metabolic reprogramming and two-compartment tumor metabolism: Opposing role(s) of hif 1alpha and hif2alpha in tumor-associated fibroblasts and human breast cancer cells. Cell Cycle 11(17): 3280-3289, 2012.

19 Lim YS, Cha W, Park MW, Jeong WJ and Ahn SH: Hif1alpha in tumorigenesis of adenoid cystic carcinoma. Anticancer Res 37(2): 599-606, 2017.

20 Hosokawa Y, Okumura K, Terashima S and Sakakura Y: Radiation protective effect of hypoxia-inducible factor-1alpha (hif-1alpha) on human oral squamous cell carcinoma cell lines. Radiat Prot Dosimetry 152(1-3): 159-163, 2012.

21 Moeller BJ, Cao Y, Li CY and Dewhirst MW: Radiation activates hif-1 to regulate vascular radiosensitivity in tumors: Role of reoxygenation, free radicals, and stress granules. Cancer Cell 5(5): 429-441, 2004.

22 Mayer A and Vaupel P: Hypoxia, lactate accumulation, and acidosis: Siblings or accomplices driving tumor progression and resistance to therapy? Adv Exp Med Biol 789: 203-209, 2013.

23 Semenza GL: Intratumoral hypoxia, radiation resistance, and hif1. Cancer Cell 5(5): 405-406, 2004.

24 Sasabe E, Zhou X, Li D, Oku N, Yamamoto T and Osaki T: The involvement of hypoxia-inducible factor-1alpha in the susceptibility to gamma-rays and chemotherapeutic drugs of oral squamous cell carcinoma cells. Int J Cancer 120(2): 268277, 2007.

25 Luo JC and Shibuya M: A variant of nuclear localization signal of bipartite-type is required for the nuclear translocation of hypoxia inducible factors (1alpha, 2alpha and 3alpha). Oncogene 20(12): 1435-1444, 2001.

26 Matsumoto S, Batra S, Saito K, Yasui H, Choudhuri R, Gadisetti C, Subramanian S, Devasahayam N, Munasinghe JP, Mitchell JB and Krishna MC: Antiangiogenic agent sunitinib transiently increases tumor oxygenation and suppresses cycling hypoxia. Cancer Res 71(20): 6350-6359, 2011.

27 Lim YC, Lee JS, Koo BS, Kim SH, Kim YH and Choi EC: Treatment of contralateral n0 neck in early squamous cell carcinoma of the oral tongue: Elective neck dissection versus observation. Laryngoscope 116(3): 461-465, 2006.

28 Lui VW, Hedberg ML, Li H, Vangara BS, Pendleton K, Zeng Y, Lu Y, Zhang Q, Du Y, Gilbert BR, Freilino M, Sauerwein S, Peyser ND, Xiao D, Diergaarde B, Wang L, Chiosea S, Seethala R, Johnson JT, Kim S, Duvvuri U, Ferris RL, Romkes M, Nukui T, Kwok-Shing Ng P, Garraway LA, Hammerman PS, Mills GB and Grandis JR: Frequent mutation of the pi3k pathway in head and neck cancer defines predictive biomarkers. Cancer Discov 3(7): 761-769, 2013.
29 Perri F, Pacelli R, Della Vittoria Scarpati G, Cella L, Giuliano $\mathrm{M}$, Caponigro F and Pepe S: Radioresistance in head and neck squamous cell carcinoma: Biological bases and therapeutic implications. Head Neck 37(5): 763-770, 2015.

30 Hennessy BT, Smith DL, Ram PT, Lu Y and Mills GB: Exploiting the pi3k/akt pathway for cancer drug discovery. Nat Rev Drug Discov 4(12): 988-1004, 2005.

31 Ocana A, Vera-Badillo F, Al-Mubarak M, Templeton AJ, Corrales-Sanchez V, Diez-Gonzalez L, Cuenca-Lopez MD, Seruga B, Pandiella A and Amir E: Activation of the $\mathrm{pi} 3 \mathrm{k} / \mathrm{mtor} / \mathrm{akt}$ pathway and survival in solid tumors: Systematic review and meta-analysis. PLoS One 9(4): e95219, 2014.

32 Courtney KD, Corcoran RB and Engelman JA: The pi3k pathway as drug target in human cancer. J Clin Oncol 28(6): 1075-1083, 2010.

33 Molinolo AA, Hewitt SM, Amornphimoltham P, Keelawat S, Rangdaeng S, Meneses Garcia A, Raimondi AR, Jufe R, Itoiz M, Gao Y, Saranath D, Kaleebi GS, Yoo GH, Leak L, Myers EM, Shintani S, Wong D, Massey HD, Yeudall WA, Lonardo F, Ensley J and Gutkind JS: Dissecting the akt/mammalian target of rapamycin signaling network: Emerging results from the head and neck cancer tissue array initiative. Clin Cancer Res 13(17): 4964-4973, 2007.

34 Yu Z, Weinberger PM, Sasaki C, Egleston BL, Speier WFt, Haffty B, Kowalski D, Camp R, Rimm D, Vairaktaris E, Burtness B and Psyrri A: Phosphorylation of akt (ser473) predicts poor clinical outcome in oropharyngeal squamous cell cancer. Cancer Epidemiol Biomarkers Prev 16(3): 553-558, 2007.

35 Onoyama M, Kitadai Y, Tanaka Y, Yuge R, Shinagawa K, Tanaka S, Yasui W and Chayama K: Combining molecular targeted drugs to inhibit both cancer cells and activated stromal cells in gastric cancer. Neoplasia 15(12): 1391-1399, 2013.

36 Manley PW, Drueckes P, Fendrich G, Furet P, Liebetanz J, Martiny-Baron G, Mestan J, Trappe J, Wartmann M and Fabbro D: Extended kinase profile and properties of the protein kinase inhibitor nilotinib. Biochim Biophys Acta 1804(3): 445-453, 2010.

37 le Coutre P, Schwarz M and Kim TD: New developments in tyrosine kinase inhibitor therapy for newly diagnosed chronic myeloid leukemia. Clin Cancer Res 16(6): 1771-1780, 2010.

38 Wakeling AE: Inhibitors of growth factor signalling. Endocr Relat Cancer 12(Suppl 1): S183-187, 2005.

39 Azzoli CG, Baker S Jr., Temin S, Pao W, Aliff T, Brahmer J, Johnson DH, Laskin JL, Masters G, Milton D, Nordquist L, Pfister DG, Piantadosi S, Schiller JH, Smith R, Smith TJ, Strawn JR, Trent D, Giaccone G and American Society of Clinical O: American society of clinical oncology clinical practice guideline update on chemotherapy for stage iv non-small-cell lung cancer. J Clin Oncol 27(36): 6251-6266, 2009.

40 Bareschino MA, Schettino C, Troiani T, Martinelli E, Morgillo $\mathrm{F}$ and Ciardiello F: Erlotinib in cancer treatment. Ann Oncol 18(Suppl 6): vi35-41, 2007.

41 Gridelli C, Bareschino MA, Schettino C, Rossi A, Maione P and Ciardiello F: Erlotinib in non-small cell lung cancer treatment: Current status and future development. Oncologist 12(7): 840849, 2007.

42 Kramer B, Hock C, Schultz JD, Lammert A, Kuhlin B, Birk R, Hormann $\mathrm{K}$ and Aderhold $\mathrm{C}$ : Impact of small molecules on betacatenin and e-cadherin expression in hpv16-positive and -negative squamous cell carcinomas. Anticancer Res 37(6): 2845-2852, 2017. 
43 Aderhold C, Faber A, Grobschmidt GM, Chakraborty A, Bockmayer A, Umbreit C, Birk R, Stern-Straeter J, Hormann K and Schultz JD: Small molecule-based chemotherapeutic approach in p16-positive and -negative hnscc in vitro. Anticancer Res 33(12): 5385-5393, 2013.

44 Roy HK, Olusola BF, Clemens DL, Karolski WJ, Ratashak A, Lynch HT and Smyrk TC: Akt proto-oncogene overexpression is an early event during sporadic colon carcinogenesis. Carcinogenesis 23(1): 201-205, 2002.

45 Guertin DA and Sabatini DM: Defining the role of mtor in cancer. Cancer Cell 12(1): 9-22, 2007.

46 Chen B, Xu X, Luo J, Wang H and Zhou S: Rapamycin enhances the anti-cancer effect of dasatinib by suppressing src/pi3k/mtor pathway in nsclc cells. PLoS One 10(6): e0129663, 2015.

47 Haltia UM, Andersson N, Yadav B, Farkkila A, Kulesskiy E, Kankainen M, Tang J, Butzow R, Riska A, Leminen A, Heikinheimo M, Kallioniemi O, Unkila-Kallio L, Wennerberg $\mathrm{K}$, Aittokallio T and Anttonen M: Systematic drug sensitivity testing reveals synergistic growth inhibition by dasatinib or mtor inhibitors with paclitaxel in ovarian granulosa cell tumor cells. Gynecol Oncol 144(3): 621-630, 2017.

48 Simioni C, Ultimo S, Martelli AM, Zauli G, Milani D, McCubrey JA, Capitani S and Neri LM: Synergistic effects of selective inhibitors targeting the pi3k/akt/mtor pathway or nup214-abl1 fusion protein in human acute lymphoblastic leukemia. Oncotarget 7(48): 79842-79853, 2016.

49 Yuge R, Kitadai Y, Shinagawa K, Onoyama M, Tanaka S, Yasui $\mathrm{W}$ and Chayama K: Mtor and pdgf pathway blockade inhibits liver metastasis of colorectal cancer by modulating the tumor microenvironment. Am J Pathol 185(2): 399-408, 2015.

50 Sabha N, Au K, Agnihotri S, Singh S, Mangat R, Guha A and Zadeh G: Investigation of the in vitro therapeutic efficacy of nilotinib in immortalized human nf2-null vestibular schwannoma cells. PLoS One 7(6): e39412, 2012.

51 Boehrer S, Galluzzi L, Lainey E, Bouteloup C, Tailler M, Harper F, Pierron G, Ades L, Thepot S, Sebert M, Gardin C, de Botton S, Fenaux P and Kroemer G: Erlotinib antagonizes constitutive activation of src family kinases and mtor in acute myeloid leukemia. Cell Cycle 10(18): 3168-3175, 2011.

52 Zhang L, Wu J, Ling MT, Zhao L and Zhao KN: The role of the pi3k/akt/mtor signalling pathway in human cancers induced by infection with human papillomaviruses. Mol Cancer 14: 87, 2015.

53 Aderhold C, Faber A, Umbreit C, Birk R, Weiss C, Sommer JU, Hormann $\mathrm{K}$ and Schultz JD: Targeting mtor and areg with everolimus, sunitinib and sorafenib in hpv-positive and -negative scc. Anticancer Res 35(4): 1951-1959, 2015.

54 Chen L, Endler A and Shibasaki F: Hypoxia and angiogenesis: Regulation of hypoxia-inducible factors via novel binding factors. Exp Mol Med 41(12): 849-857, 2009.
55 Wang WM, Zhao ZL, Ma SR, Yu GT, Liu B, Zhang L, Zhang WF, Kulkarni AB, Sun ZJ and Zhao YF: Epidermal growth factor receptor inhibition reduces angiogenesis via hypoxiainducible factor-1alpha and notch1 in head neck squamous cell carcinoma. PLoS One 10(2): e0119723, 2015.

56 Wang WM, Zhao ZL, Zhang WF, Zhao YF, Zhang L and Sun ZJ: Role of hypoxia-inducible factor-1alpha and cd146 in epidermal growth factor receptor-mediated angiogenesis in salivary gland adenoid cystic carcinoma. Mol Med Rep 12(3): 3432-3438, 2015.

57 Pore N, Jiang Z, Gupta A, Cerniglia G, Kao GD and Maity A: Egfr tyrosine kinase inhibitors decrease vegf expression by both hypoxia-inducible factor (hif)-1-independent and hif-1dependent mechanisms. Cancer Res 66(6): 3197-3204, 2006.

58 Lin YC, Wu MH, Wei TT, Chuang SH, Chen KF, Cheng AL and Chen CC: Degradation of epidermal growth factor receptor mediates dasatinib-induced apoptosis in head and neck squamous cell carcinoma cells. Neoplasia 14(6): 463-475, 2012.

59 Kramer B, Hock C, Birk R, Sauter A, Stuck BA, Hormann K, Schultz JD and Aderhold C: Targeted therapies in hpv-positive and -negative hnscc - alteration of egfr and vegfr- 2 expression in vitro. Anticancer Res 36(6): 2799-2807, 2016.

60 Formisano L, D'Amato V, Servetto A, Brillante S, Raimondo L, Di Mauro C, Marciano R, Orsini RC, Cosconati S, Randazzo A, Parsons SJ, Montuori N, Veneziani BM, De Placido S, Rosa R and Bianco R: Src inhibitors act through different mechanisms in non-small cell lung cancer models depending on egfr and ras mutational status. Oncotarget 6(28): 26090-26103, 2015.

61 Kim SH, Koo BS, Kang S, Park K, Kim H, Lee KR, Lee MJ, Kim JM, Choi EC and Cho NH: Hpv integration begins in the tonsillar crypt and leads to the alteration of p16, egfr and c-myc during tumor formation. Int J Cancer 120(7): 1418-1425, 2007.

62 Liu F, Lin B, Liu X, Zhang W, Zhang E, Hu L, Ma Y, Li X and Tang X: Erk signaling pathway is involved in hpv-16 e6 but not e7 oncoprotein-induced hif-1alpha protein accumulation in nsclc cells. Oncol Res 23(3): 109-118, 2016.

63 Huang J, Soffer SZ, Kim ES, McCrudden KW, Huang J, New T, Manley CA, Middlesworth W, O'Toole K, Yamashiro DJ and Kandel JJ: Vascular remodeling marks tumors that recur during chronic suppression of angiogenesis. Mol Cancer Res 2(1): 3642,2004

64 Lee SH, Jeong D, Han YS and Baek MJ: Pivotal role of vascular endothelial growth factor pathway in tumor angiogenesis. Ann Surg Treat Res 89(1): 1-8, 2015.

Received December 24, 2017

Revised January 25, 2018

Accepted February 5, 2018 